\title{
Quality Characteristics and Antioxidant Activity of Yogurt Containing Raw Omija and Sugared Omija during Storage
}

\author{
Won-Young Cho $\mathbb{D}$, Sung-Hyun Hwa, Fengqi Yang, and Chi-Ho Lee $\mathbb{i}$ \\ Department of Food Science and Biotechnology of Animal Resources, Konkuk University, Seoul 05029, Republic of Korea \\ Correspondence should be addressed to Chi-Ho Lee; leech@konkuk.ac.kr
}

Received 13 July 2020; Revised 18 August 2020; Accepted 20 August 2020; Published 13 October 2020

Academic Editor: Ioannis G. Roussis

Copyright (c) 2020 Won-Young Cho et al. This is an open access article distributed under the Creative Commons Attribution License, which permits unrestricted use, distribution, and reproduction in any medium, provided the original work is properly cited.

\begin{abstract}
This study was conducted to determine the quality characteristics and antioxidant properties of yogurt containing omija extract (control, raw omija, and sugared omija) stored at $4^{\circ} \mathrm{C}$ for 14 days. The $\mathrm{pH}$ of all groups decreased, while the titratable acidity increased as the storage period increased. The viscosity of the sugared omija sample was high, while in the syneresis test, the sugared omija sample showed a low value. The total polyphenol content was the highest in the raw omija sample on day 0 . DPPH activity was the highest in the raw omija sample for all storage periods; this sample also showed high $\mathrm{Fe}^{2+}$ chelating activity, which did not significantly differ from the sugared omija sample. In sensory evaluation, the sugared omija sample showed the highest overall score. Based on these results, it can be concluded that yogurt containing sugared omija shows improved quality and antioxidant activity.
\end{abstract}

\section{Introduction}

The nutritional characteristics and health advantages of yogurt have gained attention among consumers [1]. The health effects of yogurt can be improved by adding probiotic strains of lactic acid bacteria (LAB) [2]. Yogurt is consumed worldwide as a fermented dairy food and has beneficial effects on the immune system and digestive system, as well as anticancer properties [3]. Farvin et al. reported that the high oxidative stability of yogurt is related to the antioxidant peptides released during milk fermentation by LAB [4]. According to a recent study, as interest in the functional properties and quality of foods has increased, the number of studies examining the fortification of dairy foods with natural ingredients has also increased. Thus, the addition of natural components such as olive leaf extract [5], green, white, and black tea [6], and wine grape pomace [7] can elevate the nutritional value of yogurt and potentially enhance its biological activities.

Omija (Schisandra chinensis) is a Korean fruit with five flavors, sweet, salty, bitter, sour, and hot [8], and is used in food and medicinal applications [9]. It has been traditionally used as a natural medicine for fatigue, antipyretic action, and improving visual activity and as a food material for beverages, fruit punches, and sugared omija [10]. Omija has functional effects exerted by its lignan compounds, such as schizandrins and gomisins [11]. Accordingly, omija exhibits antioxidant [12], cancer inhibition [13], and liver protection activities [14]. Lee et al. reported that the main lignan of omija is schizandrin, with the seed containing the highest schizandrin content [11]. However, the seed and peel of omija are discarded after sugared omija is prepared, or juice is extracted from the fruit [11]. To utilize the lignan compound, it is considered necessary to use the omija seed portion separated from the sugared omija. Thus, this study was performed to determine the effects of adding sugared omija, a byproduct of juice extraction processing, and raw omija extract to yogurt for the quality characteristics and antioxidant properties of yogurt, during storage.

\section{Materials and Methods}

Raw omija and sugared omija were purchased in dry form from Mungyoung Mall (Mungyeong-si, Gyeongsangbuk-do, Korea) and ground using a blender (NFM-9960, NUC. Co., 
Ltd., Daegu, Korea). LAB used as a yogurt fermentation starter (Lyofast YAB 450 AB, Sacco srl., Codarago, Italy) consisted of Streptococcus thermophilus, Lactobacillus delbrueckii ssp. bulgaricus, Lactobacillus acidophilus, and Bifidobacterium animalis ssp. lactis.

2.1. Raw Omija and Sugared Omija Extract. Raw omija powder $(50 \mathrm{~g})$ and sugared omija powder $(50 \mathrm{~g})$ were each diluted by 10 -fold with distilled water. Extraction was performed at $60^{\circ} \mathrm{C}$ and $150 \mathrm{rpm}$ in a shaking incubator for $6 \mathrm{~h}$, followed by centrifugation $(3000 \mathrm{~g}, 5 \mathrm{~min})$ and then filtration through Whatman filter paper No. 4 (Whatman plc, Maidstone, UK).

2.2. Preparation of Yogurt. Milk samples containing skim milk powder, pectin, white sugar, and omija extract $(0 \%$; CON, $0.5 \%$ raw omija extract; $\mathrm{RO}$ or $0.5 \%$ sugared omija extract; SO) were homogenized with a homogenizer for 5 min (HG-15A, Daihan Scientific Co., Wonju, Korea). After homogenization, the samples were pasteurized by heating for $30 \mathrm{~min}$ at $85^{\circ} \mathrm{C}$, cooled to $42^{\circ} \mathrm{C}$ in a water bath, and incubated with $\mathrm{LAB}$ until the $\mathrm{pH}$ reached 4.5 at $37^{\circ} \mathrm{C}$ after $8 \mathrm{~h}$. These samples were stored overnight at $4^{\circ} \mathrm{C}$. Samples were collected after 1,7 , and 14 days for analysis.

2.3. $\mathrm{pH}$ and Titratable Acidity. $\mathrm{pH}$ was measured using a $\mathrm{pH}$ meter ( $\mathrm{pH}$ 900, Precisa Co., Dietikon, Switzerland). Titratable acidity (TA) was determined for all groups through neutralization titration until the $\mathrm{pH}$ reached 8.3 using distilled water ( $3 \mathrm{~g}$ of stored yogurt sample in $27 \mathrm{~mL}$ of distilled water). Next, $0.1 \mathrm{~N} \mathrm{NaOH}$ was used to estimate the amount of lactic acid (\%) using the following equation:

$$
\mathrm{LA} \%=\left[\frac{\left(10 \times \mathrm{V}_{\mathrm{NaOH}} \times 0.009 \times 0.1\right)}{\mathrm{W}}\right] \times 100,
$$

where 10 =dilution factor; $\mathrm{W}=$ weight of sample $(\mathrm{g})$ for titration; $\mathrm{V}_{\mathrm{NaOH}}=$ volume of $\mathrm{NaOH}$ used to neutralize the lactic acid; $0.1=$ normality of $\mathrm{NaOH}$.

2.4. $L A B$. The number of $\mathrm{LAB}$ was determined using the streak plate method with MRS agar (Oxoid Ltd., Hampshire, $\mathrm{UK})$. To measure the number of LAB, each sample $(100 \mu \mathrm{L})$ was serially diluted with $0.85 \% \mathrm{NaCl}$ solution $(900 \mu \mathrm{L})$. After spreading the diluted solution $(100 \mu \mathrm{L})$ onto MRS agar plates, they were cultured at $37^{\circ} \mathrm{C}$ for $24 \mathrm{~h}$. The total number of viable cells was expressed as a log value.

2.5. Viscosity and Syneresis. The viscosity of the yogurt samples stored at $4^{\circ} \mathrm{C}$ was determined using a viscometer (Model LVDV-E, Brookfield Engineering Laboratories, Inc., Middleboro, MA, USA). Measurements were performed at $30 \mathrm{rpm}$ every minute using Spindle No. 3 on the instrument for 5-8 min. Syneresis of the yogurt was measured as described by Keogh and O'Kennedy with some modifications. In brief, the yogurt $(20 \mathrm{~g})$ was centrifuged at $3000 \mathrm{~g}$ for
$10 \mathrm{~min}$ at $4^{\circ} \mathrm{C}$ [15]. The difference in weight between the residue and supernatant was calculated as follows:

$$
\text { syneresis }=\frac{\text { weight of supernatant }(\mathrm{g})}{\text { weight of sample }(\mathrm{g})} \times 100 \% \text {. }
$$

2.6. Color Measurement. Color was measured using a colorimeter (NR-300, Nippon Denshoku, Tokyo, Japan), which was calibrated before measurements using a standard white plate supplied with the instrument. Lightness (CIE L*), redness (CIE $\left.\mathrm{a}^{*}\right)$, and yellowness (CIE $\mathrm{b}^{*}$ ) values were measured three times for each treatment group.

2.7. Total Polyphenol Content (TPC). TPC was measured as described by Wei et al. with slight modifications [16]. In brief, after mixing $100 \mathrm{~mL}$ of sample that had been diluted by 10 -fold and $100 \mathrm{~mL}$ of Folin-Ciocalteu phenol reagent $(1 \mathrm{~N}$ solution), the mixture was allowed to react at room temperature for $3 \mathrm{~min}$. Next, $1 \mathrm{~N} \mathrm{Na}_{2} \mathrm{CO}_{3}$ solution $(300 \mathrm{~mL})$ was added to the mixture and incubated at room temperature for $90 \mathrm{~min}$, after which $1 \mathrm{~mL}$ of distilled water was added to complete the reaction. The absorbance of the mixture was measured at a wavelength of $725 \mathrm{~nm}$ with a spectrophotometer (OPTIZEN 2120 UV, Mecasys Co., Ltd., Seoul, Korea).

2.8. DPPH Radical Scavenging Activity and $\mathrm{Fe}^{2+}$ Chelating Activity Iron Assay. DPPH free radical scavenging activities (1,1-diphenyl-2-picrylhydrazyl) in the 10-fold diluted sample solutions were measured as described by Blois [17]. In brief, $100 \mathrm{~mL}$ of the sample extract and $100 \mathrm{~mL}$ of $0.15 \mathrm{mM}$ DPPH solution were reacted in the dark at room temperature for $30 \mathrm{~min}$. The absorbance was then measured at a wavelength of $517 \mathrm{~nm}$ on a microplate spectrophotometer (Bio-tek, Winooski, VT, USA).

$\mathrm{Fe}^{2+}$ chelating activity was determined as described by Dinis et al. [18]. $\mathrm{Fe}^{2+}$ was analyzed by measuring the formation of ferrous iron-ferrozine complex. The mixture consisted of $184 \mathrm{~mL}$ distilled water, ferrous chloride $(4 \mathrm{~mL}$ and $2 \mathrm{mM}$ ), ferrozine ( $8 \mathrm{~mL}$ and $5 \mathrm{mM}$ ), and $4 \mathrm{~mL}$ of sample in a 96-well plate. After incubation at room temperature for $10 \mathrm{~min}$, the absorbance of the mixture was measured at a wavelength of $562 \mathrm{~nm}$.

2.9. Organoleptic Evaluation. Organoleptic evaluation of the $\mathrm{CON}, \mathrm{RO}$, and $\mathrm{SO}$ samples was performed at 1 day after production (stored at $4^{\circ} \mathrm{C}$ ). Samples were evaluated by 10 untrained panelists (4 males and 6 females; age range, 24-31 years) who are members of Konkuk University (Seoul, Korea). Each evaluated item was given a score on a 7-point hedonic scale: liked extremely $=7$, liked very much $=6$, liked moderately $=5$, neither liked nor disliked $=4$, disliked moderately $=3$, disliked very $\operatorname{much}=2$, and disliked extremely $=1$. The evaluation items included color, flavor, sweet, sour, texture, and overall. 
2.10. Statistical Analysis. All data from three replicate measurements were analyzed by one-way analysis of variance using SPSS/PC Statistics 23.0 software (SPSS, Inc., Chicago, IL, USA). Data are presented as the means and standard deviation. All experiments were performed in three replicates. Tukey's multiple range tests were used to determine the significance of differences among the reported mean values; statistical significance was considered when the $P$ value was less than $0.05(P<0.05)$.

\section{Results and Discussion}

3.1. $\mathrm{pH}, \mathrm{TA}$, and $L A B$. The changes in $\mathrm{pH}, \mathrm{TA}$, and total $\mathrm{LAB}$ counts of yogurts during storage are shown in Table 1. The sample $\mathrm{pH}$ at the beginning of storage was 4.55-4.57, which decreased to $\mathrm{pH} 4.22-4.38$ after 14 days of storage. $\mathrm{pH}$ decreased in all groups as the storage time increased but did not show significant differences until day $7(P>0.05)$, after which significant differences were observed $(P<0.05)$. Lactose fermentation decreased the $\mathrm{pH}$ during the storage period [19]. This may be because the conversion of lactose to lactic acid is increased by the metabolic activity of bacteria [7]. According to Lee and Hwang', the range of optimum $\mathrm{pH}$ of coming into the market thick fermented milk is 3.27-4.59 [20]. In this study, yogurt stored for 14 days showed a $\mathrm{pH}$ within this range, indicating no difference in quality compared to fermented milk available on the market.

The initial TA of yogurt was $0.94-1.01 \%$. After 15 days, the value increased to $0.99-1.05 \%$. The titratable acidity value increased as the storage period was prolonged, but only the CON showed a significant difference compared to the experimental group $(P>0.05)$. TA is influenced by the level of nonfat solid substances such as citrates, proteins, and phosphates [21]. Davis found that the TA of market thick fermented milk can reach $0.72-1.20 \%$, which is similar to the range of TA determined in this study [22]. LAB counts in the CON sample increased as the storage period increased $(P<0.05)$, but there was no significant difference after day 7. The number of LAB in the RO and SO samples increased until day $7(P<0.05)$ and then decreased slightly, but the difference was not significant. LAB counts in all yogurt groups were over $7.0 \log \mathrm{CFU} / \mathrm{g}$, which is the minimum requirements of Codex. The RO and SO did not adversely affect the growth of $\mathrm{LAB}$ on yogurt.

3.2. Viscosity and Syneresis. The values for viscosity and syneresis of yogurt stored at $4^{\circ} \mathrm{C}$ for 14 days are shown in Table 2. The viscosity of all samples decreased over a longer storage period, but with no significant difference $(P>0.05)$. The SO and CON groups showed higher viscosities than the $\mathrm{RO}$ group $(P<0.05)$. The higher viscosity of the SO sample than the RO sample suggests that stickiness remained in the SO group, which may have also affected the extract. Syneresis tended to increase in all groups as the storage period was prolonged $(P<0.05)$. Additionally, the SO sample showed the lowest syneresis $(P<0.05)$. Syneresis is directly affected by acidity and inversely proportional to $\mathrm{pH}$ [23]. Acidification reduces the net negative electric charge of casein micelles by steadily dissolving calcium and inorganic phosphate. When the $\mathrm{pH}$ was decreased (particularly below 4.6), casein approaches the isoelectric point and electrostatic repulsions are minimized through the promotion of proteinprotein interactions $[24,25]$. Even a slight reduction in $\mathrm{pH}$ reduces the electric charge, which reduces colloid stability [26]. Whey separation is generally influenced by physical properties during storage and can be prevented by increasing the total solid content of the added stabilizer [27].

3.3. Color Measurements. The values of color $\mathrm{L}^{*}, \mathrm{a}^{*}$, and $\mathrm{b}^{*}$ of the yogurt stored at $4^{\circ} \mathrm{C}$ for 14 days are presented in Table 3. The $\mathrm{L}^{*}$ value was highest in the order of $\mathrm{CON}>\mathrm{SO}>\mathrm{RO}$, and the $\mathrm{a}^{*}$ value was highest in the $\mathrm{RO}$ group, which was considered to be an effect of the anthocyanin red pigment of the omija extract. As storage periods increased, the values for $\mathrm{L}^{*}, \mathrm{a}^{*}$, and $\mathrm{b}^{*}$ decreased. Peker and Arslan found that the $\mathrm{L}^{*}$ and $\mathrm{b}^{*}$ values of yogurt were consistently decreased during storage, which agrees with the results with our study [28]. Coggins et al. showed that yogurt had a very light cream color early in the storage period and became darker with increasing storage periods and temperatures [29]. It was shown that the $\mathrm{a}^{*}$ values of RO and SO decreased during the storage period. Samples demonstrated this parameter, indicating that the color changed from red to orange during storage mostly due to the decomposition of anthocyanins or the formation of yellow and brown polymeric compounds [30].

3.4. TPC. The TPC of the yogurts is shown in Figure 1. On day 1, the total phenolic content of yogurt was $25.89 \mathrm{mg}$ $\mathrm{GAE} / 100 \mathrm{~g}$ for the RO sample and $25.29 \mathrm{mg}$ GAE/100 $\mathrm{g}$ for the SO sample. The CON sample exhibited a significantly lower value of $22.43 \mathrm{mg} \mathrm{GAE} / 100 \mathrm{~g}(P<0.05)$. The TPC of all groups tended to decrease as the storage period increased. The Folin-Ciocalteu reactivity of plain yogurts is derived from milk components such as free amino acids, peptides, proteins, and low-molecular-weight antioxidants, as well as polyphenols [3]. This is consistent with the results of a previous study showing that the TPC values of yogurt containing grape and callus extracts were decreased when the storage period was prolonged [31]. A temporary decrease in the TPC of yogurt may result from decomposition of polymeric phenolics in the presence of LAB during refrigerated storage [32].

\subsection{DPPH Radical Scavenging Activity and Fe2+ Chelating} Activity. To investigate the antioxidant activity of the yogurts, DPPH radical scavenging activity and $\mathrm{Fe}^{2+}$ chelating activity were examined (Table 4). DPPH analysis was primarily used to measure the free radical scavenging activity of natural antioxidants. When DPPH radicals are reduced to stable diamagnetism molecules, the color of the sample becomes violet to yellow. The DPPH value of the RO sample was highest during all storage periods $(P<0.05)$. There was no significant difference between the $\mathrm{SO}$ and CON samples 
TABLE 1: pH, titratable acidity, and lactic acid bacteria during the storage of yogurt.

\begin{tabular}{|c|c|c|c|c|}
\hline & Storage period $(\mathrm{d})$ & $\mathrm{CON}$ & $\mathrm{RO}$ & $\mathrm{SO}$ \\
\hline \multirow{3}{*}{$\mathrm{pH}$} & 0 & $4.57 \pm 0.11^{\mathrm{ns}, \mathrm{A}}$ & $4.55 \pm 0.03^{\mathrm{A}}$ & $4.56 \pm 0.01^{\mathrm{A}}$ \\
\hline & 7 & $4.45 \pm 0.00^{\mathrm{b}, \mathrm{A}}$ & $4.47 \pm 0.05^{\mathrm{ab}, \mathrm{A}}$ & $4.55 \pm 0.04^{\mathrm{a}, \mathrm{A}}$ \\
\hline & 14 & $4.22 \pm 0.07^{\mathrm{ns}, \mathrm{B}}$ & $4.29 \pm 0.08^{\mathrm{B}}$ & $4.38 \pm 0.02^{\mathrm{B}}$ \\
\hline \multirow{3}{*}{ Titratable acidity (\%) } & 0 & $0.94 \pm 0.01^{\mathrm{b}, \mathrm{B}}$ & $1.01 \pm 0.01^{\mathrm{a}, \mathrm{NS}}$ & $0.97 \pm 0.01^{b, N S}$ \\
\hline & 7 & $0.97 \pm 0.02^{\mathrm{ns}, \mathrm{AB}}$ & $1.03 \pm 0.07$ & $0.98 \pm 0.01$ \\
\hline & 14 & $0.99 \pm 0.02^{\mathrm{ns}, \mathrm{A}}$ & $1.05 \pm 0.08$ & $0.99 \pm 0.01$ \\
\hline \multirow{3}{*}{ Lactic acid bacteria $(\log \mathrm{CFU} / \mathrm{mL})$} & 0 & $7.28 \pm 0.19^{\mathrm{ns}, \mathrm{B}}$ & $7.46 \pm 0.15^{\mathrm{B}}$ & $7.50 \pm 0.17^{\mathrm{B}}$ \\
\hline & 7 & $7.86 \pm 0.09^{\mathrm{ns}, \mathrm{A}}$ & $8.03 \pm 0.07^{\mathrm{A}}$ & $8.03 \pm 0.11^{\mathrm{A}}$ \\
\hline & 14 & $7.95 \pm 0.05^{\mathrm{ns}, \mathrm{A}}$ & $7.86 \pm 0.08^{\mathrm{A}}$ & $7.87 \pm 0.07^{\mathrm{A}}$ \\
\hline
\end{tabular}

CON: control; RO: raw omija; SO: sugared omija. Means with different superscripts ( ${ }^{\mathrm{A}, \mathrm{B}}$ in the same column and ${ }^{\mathrm{a}, \mathrm{b}}$ in the same row) differ significantly $(P<0.05)$. All values are represented as mean \pm standard deviation for three replicates. NS : not significant.

TABLE 2: Viscosity and syneresis during the storage of yogurts.

\begin{tabular}{lcccc}
\hline & Storage period (d) & CON & RO & SO \\
\hline & 0 & $123.03 \pm 6.60^{\mathrm{a}, \mathrm{NS}}$ & $75.30 \pm 5.14^{\mathrm{b}, \mathrm{NS}}$ & $145.38 \pm 16.19^{\mathrm{a}, \mathrm{NS}}$ \\
Viscosity (cp) & 7 & $120.01 \pm 15.78^{\mathrm{a}}$ & $71.66 \pm 4.64^{\mathrm{b}}$ & $134.81 \pm 13.19^{\mathrm{a}}$ \\
& 14 & $102.73 \pm 5.26^{\mathrm{a}}$ & $68.13 \pm 9.48^{\mathrm{b}}$ & $113.70 \pm 15.42^{\mathrm{a}}$ \\
Syneresis (\%) & 0 & $45.58 \pm 1.56^{\mathrm{b}, \mathrm{A}}$ & $57.74 \pm 2.02^{\mathrm{a}, \mathrm{A}}$ & $40.45 \pm 0.86^{\mathrm{c}, \mathrm{A}}$ \\
& 7 & $57.38 \pm 1.77^{\mathrm{b}, \mathrm{B}}$ & $66.20 \pm 2.81^{\mathrm{a}, \mathrm{B}}$ & $51.48 \pm 3.51^{\mathrm{b}, \mathrm{B}}$ \\
\hline
\end{tabular}

CON: control; RO: raw omija; SO: sugared omija. Means with different superscripts $\left({ }^{\mathrm{A}-\mathrm{C}}\right.$ in the same column and ${ }^{\mathrm{a}, \mathrm{b}}$ in the same row) differ significantly $(P<0.05)$. All values are represented as mean \pm standard deviation for three replicates. NS: not significant.

TABLE 3: Color during the storage of yogurts.

\begin{tabular}{|c|c|c|c|c|}
\hline \multirow{2}{*}{ Color value } & \multirow{2}{*}{ Storage period (d) } & \multicolumn{3}{|c|}{ Treatment } \\
\hline & & $\mathrm{CON}$ & RO & $\mathrm{SO}$ \\
\hline \multirow{3}{*}{$\mathrm{L}^{*}$ value } & 0 & $85.01 \pm 1.35^{\mathrm{a}, \mathrm{NS}}$ & $80.28 \pm 0.43^{\mathrm{b}, \mathrm{NS}}$ & $83.76 \pm 0.95^{\mathrm{a}, \mathrm{A}}$ \\
\hline & 7 & $84.50 \pm 1.19^{\mathrm{a}}$ & $80.17 \pm 0.65^{\mathrm{b}}$ & $82.22 \pm 0.77^{\mathrm{b}, \mathrm{A}}$ \\
\hline & 14 & $83.34 \pm 2.50^{\mathrm{ns}}$ & $79.71 \pm 1.01$ & $79.93 \pm 0.61^{\mathrm{B}}$ \\
\hline \multirow{3}{*}{$\mathrm{a}^{*}$ value } & 0 & $-2.96 \pm 0.19^{\mathrm{b}, \mathrm{NS}}$ & $-0.53 \pm 0.01^{\mathrm{a}, \mathrm{A}}$ & $-2.80 \pm 0.04^{\mathrm{b}, \mathrm{A}}$ \\
\hline & 7 & $-2.97 \pm 0.20^{\mathrm{b}}$ & $-0.61 \pm 0.03^{\mathrm{a}, \mathrm{B}}$ & $-2.85 \pm 0.07^{\mathrm{b}, \mathrm{A}}$ \\
\hline & 14 & $-3.35 \pm 0.03^{c}$ & $-0.86 \pm 0.02^{\mathrm{a}, \mathrm{C}}$ & $-3.02 \pm 0.05^{\mathrm{b}, \mathrm{B}}$ \\
\hline \multirow{3}{*}{$\mathrm{b}^{*}$ value } & 0 & $6.61 \pm 0.08^{\mathrm{b}, \mathrm{A}}$ & $9.26 \pm 0.24^{\mathrm{a}, \mathrm{A}}$ & $6.74 \pm 0.13^{\mathrm{b}, \mathrm{A}}$ \\
\hline & 7 & $6.47 \pm 0.05^{\mathrm{b}, \mathrm{A}}$ & $8.96 \pm 0.09^{\mathrm{a}, \mathrm{AB}}$ & $6.66 \pm 0.08^{\mathrm{b}, \mathrm{A}}$ \\
\hline & 14 & $6.23 \pm 0.10^{\mathrm{b}, \mathrm{B}}$ & $8.63 \pm 0.07^{\mathrm{a}, \mathrm{B}}$ & $5.60 \pm 0.19^{\mathrm{c}, \mathrm{B}}$ \\
\hline
\end{tabular}

CON: control; RO: raw omija; SO: sugared omija. Means with different superscripts $\left({ }^{\mathrm{A}-\mathrm{C}}\right.$ in the same column and ${ }^{\mathrm{a}, \mathrm{b}}$ in the same row) differ significantly $(P<0.05)$. All values are represented as means \pm standard deviation for three replicates. NS : not significant.

until day $7(P>0.05)$; the SO sample showed a higher value than the CON sample on day $14(P<0.05)$.

$\mathrm{Fe}^{2+}$ chelating activity resulted in the formation of a complex, and the sample turned to purple. The chelating activity of the sample can inhibit formation of $\mathrm{Fe}^{2+}$-ferrozine complexes. In all groups, $\mathrm{Fe}^{2+}$ chelating activity tended to decrease with increasing storage periods $(P<0.05)$. There was no significant difference between the RO and SO samples during the storage period $(P<0.05)$. The antioxidant activities of phenolic compounds of internal plants are highly correlated [33]. Protein degradation by lactic acid bacteria can release bioactive peptides with antioxidant activity in fermented milk products [4]. Additionally, the hydrolysis of milk protein or organic acid production may explain the antioxidant activity, which occurs because of microbial metabolic activity during fermentation and refrigerated storage. Decreased antioxidant activity of samples during storage may be related to milk-polyphenol interactions, which may lead to decreased antioxidant capacity [34]. Thus, proline rich casein may lead to precipitation of phenolic compounds and reduce the antioxidant potential [35].

3.6. Sensory Evaluation. The results of sensory evaluation of yogurt containing $\mathrm{RO}$ and $\mathrm{SO}$ are shown in Figure 2. The color of the CON sample was highest with a value of 5.80 and that of the SO sample was 5.60. Flavor showed the highest score in the SO sample with a value of 5.30, and the CON and RO samples showed the same score of 4.30 . Sweet flavor in 


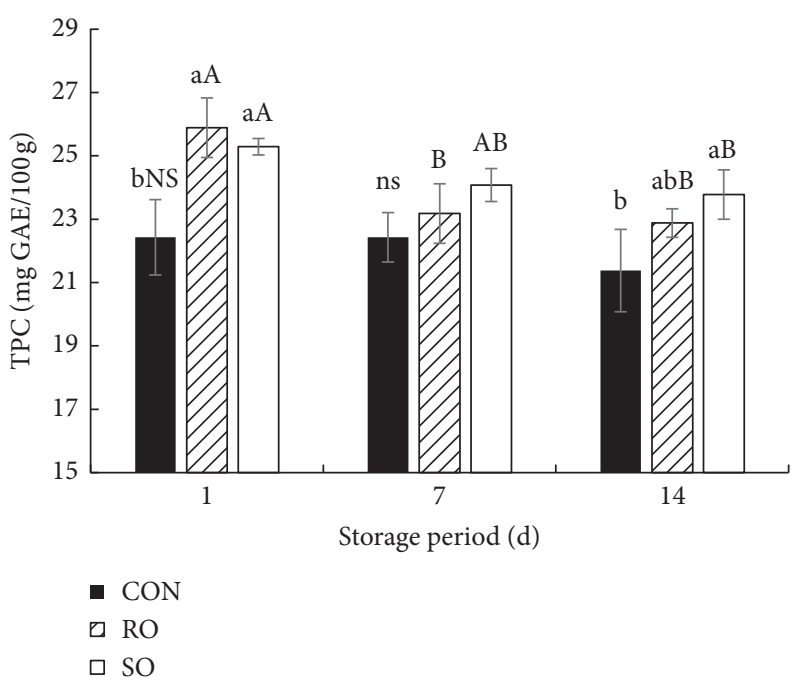

FIGURE 1: Changes in total polyphenol content (TPC) during storage of yogurt. CON: control; RO: raw omija; SO: sugared omija. Means with different superscripts (A, B in the same column and a, b in the same row) differ significantly $(P<0.05)$. All values are represented as mean \pm standard deviation for three replicates. NS : not significant.

TABLe 4: Antioxidant activities during the storage of yogurts.

\begin{tabular}{lcccc}
\hline & Storage period (d) & CON & RO & SO \\
\hline & 0 & $56.52 \pm 2.40^{\mathrm{b}, \mathrm{A}}$ & $64.69 \pm 0.91^{\mathrm{a}, \mathrm{A}}$ & $58.23 \pm 1.14^{\mathrm{b}, \mathrm{A}}$ \\
DPPH (\%) & 7 & $56.13 \pm 0.40^{\mathrm{b}, \mathrm{A}}$ & $62.71 \pm 0.23^{\mathrm{a}, \mathrm{B}}$ & $55.47 \pm 1.27^{\mathrm{b}, \mathrm{B}}$ \\
& 14 & $46.64 \pm 1.19^{\mathrm{c}, \mathrm{B}}$ & $62.71 \pm 0.60^{\mathrm{a}, \mathrm{B}}$ & $53.89 \pm 0.60^{\mathrm{b}, \mathrm{B}}$ \\
\hline \multirow{2}{*}{$\mathrm{Fe}^{2+}$ chelating activity (\%) } & 0 & $36.38 \pm 1.87^{\mathrm{b}, \mathrm{NS}}$ & $43.09 \pm 1.28^{\mathrm{a}, \mathrm{NS}}$ & $41.04 \pm 2.57^{\mathrm{ab}, \mathrm{NS}}$ \\
& 7 & $35.62 \pm 0.76^{\mathrm{b}}$ & $43.00 \pm 3.09^{\mathrm{a}}$ & $39.51 \pm 0.85^{\mathrm{ab}}$ \\
\hline
\end{tabular}

CON: control; RO: raw omija; SO: sugared omija. Means with different superscripts ( ${ }^{\mathrm{A}, \mathrm{B}}$ in the same column and ${ }^{\mathrm{a}-\mathrm{c}}$ in the same row) differ significantly $(P<0.05)$. All values are represented as mean \pm standard deviation for three replicates. NS : not significant.

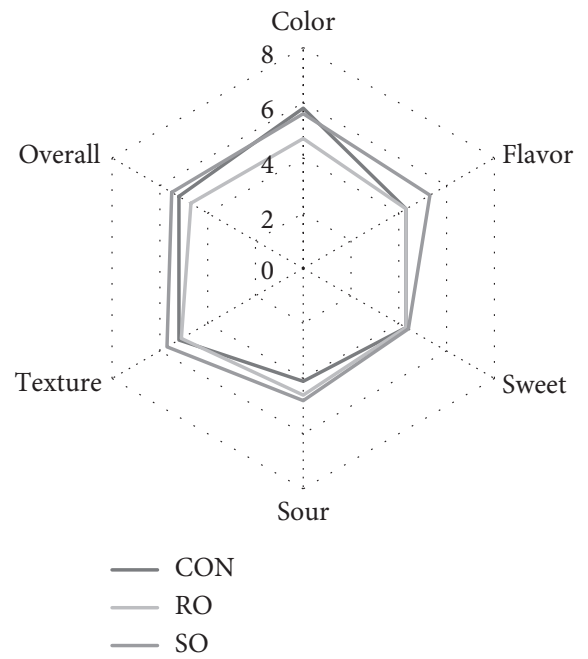

FIGURE 2: Sensory test results of yogurts. CON: control; RO: raw omija; SO: sugared omija.

the SO group exhibited a value of 4.40 , and the CON and RO samples had values of 4.30 . The SO sample showed a value of 4.80 for sour and 5.7 for texture. Overall, the value for the SO sample was the highest at 5.50, CON sample was 5.20, and RO sample was 4.70. Except for the color score, the SO sample showed the highest value in all groups, but the difference was not significant $(P>0.05)$. Sweetness can influence sensory characteristics, and the overall value of the SO sample was highest.

\section{Conclusions}

All yogurts containing omija showed reasonable ranges for $\mathrm{pH}, \mathrm{TA}$, and LAB counts during storage. Viscosity and syneresis were improved by adding $\mathrm{SO}$ to the yogurt. In sensory evaluation, the SO sample showed the highest overall value of 5.50. The phenolic compounds in the RO and SO samples increased the antioxidant activity and total phenolic compounds in the yogurt. In conclusion, we confirmed that adding sugared omija to yogurt improves its quality, antioxidant activity, and sensory properties.

\section{Data Availability}

The data used to support the findings of this study are available from the corresponding author upon request. 


\section{Conflicts of Interest}

The authors declare that they have no conflicts of interest.

\section{References}

[1] S. Cakmakci, D. Tahmas-Kahyaoglu, T. Erkaya, K. Cebi, and A. A. Hayaloglu, " $\beta$-carotene contents and quality properties of set type yoghurt supplemented with carrot juice and sugar," Journal of Food Processing and Preservation, vol. 38, no. 3, pp. 1155-1163, 2014.

[2] N. P. Shah, "Functional cultures and health benefits," International Dairy Journal, vol. 17, no. 11, pp. 1262-1277, 2007.

[3] A. Helal and D. Tagliazucchi, "Impact of in-vitro gastropancreatic digestion on polyphenols and cinnamaldehyde bioaccessibility and antioxidant activity in stirred cinnamonfortified yogurtin-vitro gastro-pancreatic digestion on polyphenols and cinnamaldehyde bioaccessibility and antioxidant activity in stirred cinnamon-fortified yogurt," LWT-Food Science and Technology, vol. 89, pp. 164-170, 2018.

[4] K. H. Farvin, C. P. Baron, N. S. Nielsen, and C. Jacobsen, "Antioxidant activity of yoghurt peptides: part 1-in vitro assays and evaluation in x-3 enriched milk," Food Chemistry, vol. 123, no. 4, pp. 1081-1089, 2010.

[5] W.-Y. Cho, D.-H. Kim, H.-J. Lee, S.-J. Yeon, and C.-H. Lee, "Quality characteristic and antioxidant activity of yogurt containing olive leaf hot water extract," CyTA - Journal of Food, vol. 18, no. 1, pp. 43-50, 2020.

[6] P. Muniandy, A. B. Shori, and A. S. Baba, "Influence of green, white and black tea addition on the antioxidant activity of probiotic yogurt during refrigerated storage," Food Packaging and Shelf Life, vol. 8, pp. 1-8, 2016.

[7] A. Tseng and Y. Zhao, "Wine grape pomace as antioxidant dietary fibre for enhancing nutritional value and improving storability of yogurt and salad dressing," Food Chemistry, vol. 138, no. 1, pp. 356-365, 2013.

[8] S.-H. Kim, M. H. Joo, and S.-H. Yoo, "Structural identification and antioxidant properties of major anthocyanin extracted from omija (schizandra chinensis) fruit," Journal of Food Science, vol. 74, no. 2, pp. C134-C140, 2009.

[9] G.-T. Chang, S.-K. Kang, J.-H. Kim, K.-H. Chung, Y.-C. Chang, and C.-H. Kim, "Inhibitory effect of the korean herbal medicine, dae-jo-whan, on platelet-activating factorinduced platelet aggregation," Journal of Ethnopharmacology, vol. 102, no. 3, pp. 430-439, 2005.

[10] G. T. Jung, I. O. Ju, J. S. Choi, and J. S. Hong, "The antioxidative, antimicrobial and nitrite scavenging effects of schizandra chinensis RUPRECHT(omija) seed," Korean Journal of Food Science and Technology, vol. 32, no. 4, pp. 928-935, 2000.

[11] K. S. Lee, B. H. Lee, B. J. Seong et al., "Chemical components composition on different parts of fruit in schisandra chinensis baillon," Journal of the Korean Society of Food Science and Nutrition, vol. 45, no. 6, pp. 851-858, 2016.

[12] H. J. Chae, H. I. Hwang, I. S. Lee, and H. Y. Moon, "Comparison of on rat intestinal digestive enzyme inhibitory activity and antioxidant enzyme activity of korean and chinese schizandra chinensis," Biomedical Science Letters, vol. 11, no. 4, pp. 517-523, 2005.

[13] M. Nomura, M. Nakachiyama, T. Hida et al., "Gomisin A, a lignan component of schizandora fruits, inhibits development of preneoplastic lesions in rat liver by $3^{\prime}$-methyl-4-dimethylamino-azobenzene," Cancer Letters, vol. 76, no. 1, pp. 11-18, 1994.
[14] J. H. Heo, J. G. Park, H. J. Cheon et al., "Hepatoprotective activities of gomisin A and gomisin N," Korean Jounral of Pharmacognosy, vol. 37, no. 4, pp. 294-301, 2006.

[15] M. K. Keogh and B. T. O’kennedy, "Rheology of stirred yogurt as affected by added milk fat, protein and hydrocolloids," Journal of Food Science, vol. 63, no. 1, pp. 108-112, 1998.

[16] X. Wei, M. Luo, L. Xu et al., "Production of fibrinolytic enzyme from bacillus amyloliquefaciens by fermentation of chickpeas, with the evaluation of the anticoagulant and antioxidant properties of chickpeas," Journal of Agricultural and Food Chemistry, vol. 59, no. 8, pp. 3957-3963, 2011.

[17] M. S. Blois, "Antioxidant determinations by the use of a stable free radical," Nature, vol. 181, 1958.

[18] T. C. P. Dinis, V. M. C. Madeira, and L. M. Almeida, "Action of phenolic derivates (acetoaminophen, salycilate, and 5aminosalycilate) as inhibitors of membrane lipid peroxidation and as peroxyl radical scavengers," Archive of Biochemistry and Biophysics, vol. 315, 1994.

[19] A. Hassan and I. Amjad, "Nutritional evaluation of yoghurt prepared by different starter cultures and their physiochemical analysis during storage," African Journal of Biotechnology, vol. 9, no. 9, pp. 2913-2917, 2010.

[20] J. H. Lee and H. J. Hwang, "Quality characteristics of curd yogurt with rubus coreanum miquel juice," Culinary Science and Hospitality Research, vol. 12, no. 2, pp. 195-205, 2006.

[21] E. Şenel, M. Atamer, A. Gürsoy, and F. Ş. Öztekin, "Changes in some properties of strained (süzme) goat's yoghurt during storage," Small Ruminant Research, vol. 99, no. 2-3, pp. 171-177, 2011.

[22] J. G. Davis, "Laboratory control of yogurt," Dairy Industries, vol. 35, no. 3, pp. 139-144, 1970.

[23] P. F. Fox, T. P. Guinee, T. M. Cogan, and P. L. H. Mcsweeney, Fundamentals of Cheese Science, Springer, Boston, MA, USA, "1st edition, 2000.

[24] J. Visser, A. Minihan, P. Smits, S. B. Tjan, and I. Heertje, "Effects of $\mathrm{pH}$ and temperature on the milk salt system," Netherlands Milk and Dairy Journal, vol. 40, no. 4, pp. 351368, 1986.

[25] S. Marchesseau, E. Gastaldi, A. Lagaude, and J.-L. Cuq, "Influence of $\mathrm{pH}$ on protein interactions and microstructure of process cheese," Journal of Dairy Science, vol. 80, no. 8, pp. 1483-1489, 1997.

[26] P. Walstra, J. T. M. Wouters, and T. J. Geurts, Dairy Science and Technology, CRC Press, Boca Raton, FL, USA, 2nd edition, 2005.

[27] R. Coda, A. Lanera, A. Trani, M. Gobbetti, and R. Di Cagno, "Yogurt-like beverages made of a mixture of cereals, soy and grape must: microbiology, texture, nutritional and sensory properties," International Journal of Food Microbiology, vol. 155, no. 3, pp. 120-127, 2012.

[28] H. Peker and S. Arslan, "Effect of olive leaf extract on the quality of low fat apricot yogurt," Journal of Food Processing Preservation, vol. 41, no. 5, Article ID e13107, 2017.

[29] P. C. Coggins, D. E. Rowe, J. C. Wilson, and S. Kumari, "Storage and temperature effects on appearance and textural characteristics of conventional milk yogurt," Journal of Sensory Stududies, vol. 25, no. 4, pp. 549-576, 2010.

[30] I. Ścibisz, M. Ziarno, and M. Mitek, "Color stability of fruit yogurt during storage," Journal of Food Science and Technology, vol. 56, no. 4, pp. 1997-2009, 2019.

[31] M. Karaaslan, M. Ozden, H. Vardin, and H. Turkoglu, "Phenolic fortification of yogurt using grape and callus extracts," LWT - Food Science and Technology, vol. 44, no. 4, pp. 1065-1072, 2011. 
[32] M. J. Dalling, Plant Proteolytic Enzymes, CRC Press, Boca Raton, FL, USA, 2nd edition, 1986.

[33] L. Pérez -fons, M. T. Garzon, and V. Micol, "Relationship between the antioxidant capacity and effect of rosemary (rosmarinus officinalis L.) polyphenols on membrane phospholipid order," Journal of Agricultural and Food Chemistry, vol. 58 , no. 1 , pp. $161-171,2010$.

[34] M. J. T. J. Arts, G. R. M. M. Haenen, L. C. Wilms et al., "Interactions between flavonoids and proteins: effect on the total antioxidant capacity," Journal of Agricultural and Food Chemistry, vol. 50, no. 5, pp. 1184-1187, 2002.

[35] Z. Yuksel, E. Avci, and Y. K. Erdem, "Characterization of binding interactions between green tea flavanoids and milk proteins," Food Chemistry, vol. 121, no. 2, pp. 450-456, 2010. 